times in Spain. Especially dramatic, if of no great scientific importance, is the account of an unusual friendship struck up between an Englishman and a gypsy youth as the result of help given in a brawl in a Montparnasse estaminet. The two eventually travelled together to visit the gypsy's parents in Madrid-shortly before the lad himself was killed in an accident.

The gypsy language naturally becomes modified by the speech of the people among whom the wanderers have penetrated. Thus Bosnian Romani shows signs of the influence of the Slavonic language with which it is most closely associated, and in this connexion a preliminary study of Bosnian Romani and of certain North Albanian texts will doubtless be of interest to language students. One cannot help wondering what these alien wanderers who still survive among so many of the warring European nations can be thinking, if they think so widely, of the present suicidal struggle of their hosts.

\section{Place-Names in the United States}

THAT the study of place-names, apart from its intrinsic interest, is an invaluable source of illuminating evidence for archæologist, anthropologist and social historian, has become a commonplace among all who are familiar with the publications of the English Place-Name Society. Analogous studies of place-names of Indian origin have been made in the United States ; but there the untrustworthy character of early documents, if not their complete absence, is a difficulty which is only partially overcome by reference to those few survivors who are still acquainted with the original Indian language. Dr. J. P. Harrington, of the Smithsonian Institution, arrives at the meaning of names of Indian origin in the eastern United States by reference to Delawares now resident in eastern Oklahoma, whose language is one of the few eastern languages still surviving, predominantly the tongue of the Pennsylvanian Indians at the time of first settlement. It is interesting to note that many place-name elements were immediately recognized by living Delawares, but others remained doubtful, even when the words were reconstructed by them out of the basic elements of their language. Of the names submitted for interpretation, "Chesapeke", for long a puzzle to students, is said to be "salt bay" from chesa $=$ salt and peekw = body of water. Susquehanna is "muddy river", and Monongahela, "caving banks". Potomac, which previously had been interpreted as "carrying place" or "centre for trading", is now construed in the opposite sense as a place where a man lays down a burden, resting place-presumably the place at which Indian war or trading parties took a rest when they came in sight of some village approximately in the present position of the city of Washington.

\section{Indian Fisheries}

A report on a survey of the fisheries of Bengal by Dr. R. Naidu (Bengal Govt. Press, 1939) which has only recently been received, contains valuable information on the present state of the Indian fisheries. There is a descriptive account of the fishing methods, followed by details of the commercially exploited groups of fishes in the different parts of Bengal and of the recent work done in other provinces to improve the fisheries. The hilsa or the Indian shad (Hilsa ilisha) is the most popular food fish of Bengal ; the report makes it clear that unless hatcheries are provided and protective legislation enacted, this valuable fishery will rapidly be depleted at the present rate of fishing. The condition of the carp fisheries, which come next in importance, is equally unsatisfactory, for, though carp culture is widely practised in Bengal, the methods in vogue are wasteful and destructive. The dried fish and prawn industries are considerably developed in the province, but the methods of preparation of the products for the market leave much to be desired. Analysis of the fishing trade points to the deplorable economic condition of the fishing populations who form the backbone of the industry; though fish are plentiful and prices high, a disproportionately high percentage of the profits go to the middlemen who intervene between the fishermen and the consumers. The recommendations made include the organization of a new department with properly equipped stations and personnel, and if given effect to, should substantially improve the fishing industry of the province. Bengal had a separate fisheries department for some time, but it was abolished in 1923. From the facts presented in the report it is difficult to understand how the fisheries of the province could be improved without a properly organized fishery administration.

It is impossible to exaggerate the necessity for developing the fisheries in a country like India where a high percentage of the population is undernourished; the supply of good fish throughout the country by efficient methods of storage and transport would not only raise the nutritional standards of the people but would form also the basis of an industry which has great scope for expansion. We understand that quick-freezing refrigeration plants have already been installed in some parts of India. There is, unfortunately, no organized plan of development of the fisheries of the country as a whole; while some provinces like Madras are ahead of the others, most provinces have no fishery departments at all. The attitude of the provincial Governments seems to be that the departments should mainly rely on their own income for expansion; this short-sighted policy has very much limited the activities of the existing departments. Much work remains to be done to elucidate the habits and life-histories of Indian food fishes. Recent work on some of them has been noticed in Nature $(146,657 ; 1940)$. The problem is too vast to be tackled by the fisheries departments alone. We venture to suggest that they should enlist the co-operation of Indian universities and other institutes which have provision for post-graduate research, by providing grants-in-aid for investigating specified problems. In any case a central body to co-ordinate the work done at the different centres would be essential. 